\title{
The Impact of RMB Appreciation on China's Stock Market
}

\author{
Mengliang Yu \\ Nanjing University of Science and Technology, Nanjing 210094, China; \\ 2642579570@qq.com
}

Keywords: RMB appreciation; exchange rate revaluation expectation; excess liquidity; stock market

\begin{abstract}
The RMB continues to hit new highs, while the Chinese stock market is constantly updating its history. The history of many countries tells us that in the process of currency appreciation, the stock market is always accompanied. China is no exception. The process of RMB appreciation will rewrite the pattern of state-owned wealth distribution. It is necessary to seize the golden period of the stock market and share the fruits of China's rapid economic growth.
\end{abstract}

\section{Introduction}

The stock index not only reflects the overall level and changes of various stock prices in the entire stock market, but also reflects the economic development of a country. The exchange rate is generally referred to as the ratio of two different currencies. Under the current economic globalization, the exchange rate has become an important economic variable in connection with domestic and foreign markets. It is of great significance to study the relationship between exchange rate and stock market. In 2005, it was China's first exchange reform. On the second day, the central parity of the RMB against the US dollar rose from 8.28 to 8.11. The Shanghai Composite Index rose on the day, thus opening the prelude to the exchange rate affecting the stock market. Even though China's capital market has not been fully opened, with the launch of the QFII and QDII projects, the mobility of international free capital into China has increased, and the path of the RMB exchange rate affecting China's stock market has begun to take shape.

In 1971, the Bretton Woods system was declared to be over, and most countries and regions in the world gradually used the floating exchange rate system. The widespread use of the floating exchange rate system, how the exchange rate affects a country's economy is widely concerned by scholars all over the world, and from the practice of these countries, the exchange rate and the economy of one country and the stock market have shown The high correlation, and even the interaction between the exchange rate and the stock price, finally caused the economic and financial crisis, which made the country's economy appear sluggish for a long time. After the Hiroshima agreement, the appreciation of the yen triggered a subsequent economic bubble as a typical example. Since the reform and opening up, China's dependence on foreign trade has gradually increased. The higher the dependence on foreign trade, the greater the ratio of total trade to GDP, so that the possibility of affecting China's 
economy through the influence of foreign trade will increase. In other words, the influence of exchange rate on the stock market and even the real economy may be stronger.

In-depth study of the impact of the exchange rate on the stock market is conducive to China's absorption of some lessons from foreign economies in development, to prevent repeating the same mistakes. For listed companies, it is beneficial for the company's management to adjust the company's strategy based on the specific circumstances of the company and the expected exchange rate changes. If necessary, hedging can be used to lock in the risk of the company; for QDII, smoothing the relationship between the exchange rate and the stock market will help some investors to better allocate the proportion of asset investment to maximize the benefits or reduce the risk.

\section{Literature review}

Since the RMB exchange rate system has been adopted before the exchange rate is linked with the US dollar fixed exchange rate system, the relationship between domestic exchange rate fluctuations and stock price research began later. The main domestic research results are as follows: He Juxiang analyzed the exchange rate changes of single business and overall stock price in 1995. She believes that free circulation and free floating exchange rates will affect stock prices to varying degrees. However, the exchange rate of individual companies is different from the stock price and the overall stock price. It is necessary to protect exchange rate risks and analyze exchange rate movements. Dombusch and Fisher's mobile flow models, which are based on domestic data, indicating that exchange rate volatility affects a country's international competitiveness, balance of payments and state enforcement affecting the company's cash flow and stock prices, and then affecting Spot and forward stock markets. Conversely, changes in the stock market will also affect changes in the exchange rate market.

Aggarwal conducted an empirical study using the US market as an example and found that exchange rate fluctuations are positively correlated with stock market returns. Bahmanr-Oskooe and Sohrabian use the Granger causality test to test the two-way causal relationship between stock market and exchange rate movements. They believe that this two-way causal relationship is at least in the short term, and that the stock market interacts and is relevant. Abdalla and Murinde (1997) show that exchange rate movements in four emerging markets, such as India, have a one-way impact on stock prices. Empirical analysis by Granger (2000) suggests that exchange rate and stock price interactions are very strong in most Asian countries and regions. Other scholars disagree. Taylor and Tonks have passed case studies in the United Kingdom, the United States, West Germany and Japan, indicating that there is no clear link between the abolition of foreign exchange controls and the growth of the stock market. In other words, exchange rate changes are relatively weak in relation to the stock market. Ajayi and Mougoue conducted cross-time analysis of the exchange rate and stock market of eight developed countries from 1985 to 1991. The appreciation of the currency obtained in the short term has a positive impact on the stock market and has no negative effect in the long run. Zhou Mei and other US monthly data analysis found that stock returns have no correlation with real exchange rate returns. McKinnon and Ono Yuki pointed out that exchange rate fluctuations, especially including exchange rate appreciation, are expected to lead to deflation, affecting consumption and investment, and ultimately affecting the stock market boom. 


\section{Theoretical basis}

\subsection{The theoretical basis of the appreciation of the RMB}

Mundell's impossible triangle theory ( $\mathrm{X}+\mathrm{Y}+\mathrm{M}=2$ ) argues that assuming that capital is free-flowing, for the central bank, only one can achieve between a completely independent and stable monetary policy exchange rate, rather than Both. The three theoretical relationships can be expressed as: The three sides of the triangle are what every central bank wants. $(\mathrm{Y}=1)$, the second side represents the complete independence of monetary policy $(M=1)$. The main sign is that the central bank can independently develop theoretical policies according to the domestic economic situation. The third-party exchange rate is stable, and every country wants Your own currency is stable, not ups and downs.

We turn the triangle into a coordinate system, which is the triangular triangle, that is, the three exchange rate systems. The current situation is that the most representative of the three major exchange rate systems is that the OECD represents a completely free floating of the exchange rate, such as the United States and Japan. China's Hong Kong monetary authorities account for both capital flows and exchange rates, but China's monetary authorities do not have monetary policy independence $(\mathrm{M}=0)$; China is also the full independence of capital and independent monetary policy. Both sides can independently formulate monetary policy and Maintain exchange rate stability, but China will implement capital exchange control, and capital cannot flow freely ( $\mathrm{Y}=0$ ).

China is a developing country with a large population and uneven development. Maintaining the independence of monetary policy for a long time is crucial. Therefore, the value of $\mathrm{M}$ will be close to 1 or equal to 1 . With the gradual opening up of banks, securities insurance business, the gradual reform of the money market, bond market and capital market, the free flow of capital will become more and more relaxed, the $\mathrm{Y}$ value will increase, but the sum must be equal to 2, M Can not be changed, must be close to 1 . With the opening of expansion, the value of Y must increase, the only change may be the decrease in the value of $\mathrm{X}$, China's exchange rate system must move towards a flexible real floating exchange rate. Regardless of China's economic growth rate, interest rates, inflation or trade surplus, and foreign exchange reserves, the RMB exchange rate has pressure to appreciate, and the pressure for RMB appreciation continues.

\subsection{The impact of RMB appreciation on the stock market}

In the process of economic rise, no country or region can avoid the problem of domestic or regional currency appreciation. Today is even more so in the increasingly globalized world economy. Between 1985 and 1989, the Asia-Pacific currency appreciated sharply, the stock market soared, the currency appreciated 56\%, the stock index rose $1380 \%$; the appreciation rose $22 \%$, and the stock index rose $626 \%$. The yen appreciated $77 \%$, the stock rose $224 \%$, or $20 \%$, and the stock rose $91 \%$. In the short term, mainly the exchange rate changes are expected to lead to the flow of speculative hot money, affecting the stock market capital supply and market interest rates, including asset prices including stocks have the same effect. There is a saying that if the $r$ rose to 5:1 before 2008, foreign investment in the Chinese stock market could only reach $10.6 \%$ compound interest.

The short-term impact of the exchange rate on the stock market is also dependent on the way the exchange rate changes. If there is no government intervention, the market exchange rate adjustment will usually reach a relatively stable level in a relatively short period of time (or even overshoot), then the exchange rate change of the space imagination space will completely disappear, and the stock market will also stabilize. In countries with foreign exchange controls and exchange rate imbalances, 
the government is reluctant to revalue the currency in order to stabilize macroeconomic considerations, but it will stimulate the market to continue to generate further revaluation expectations, leading to a sharp shock in the stock market's rise for a long time.

\section{Empirical analysis}

\subsection{Data selection}

This paper selects the closing price of the Shanghai Composite Index from January 2017 to January 2018 and the middle price of the exchange rate of the RMB against the US dollar. A total of 244 sets of daily data.

\subsection{Stationarity test}

Before we perform regression analysis on the time series, we must first conduct a stationarity test. If the financial data examined are not stationary, then the result of the regression is false. We usually use the unit root test to verify the station's stationarity. If there is no unit root in the test result, then the time series is stable; otherwise, it is not stable. There are three main methods that we often use to do unit root tests: DF test, ADF test and PP test. The ADF test method is commonly used at present, so this method is also used in this paper. The test results are as follows:

Table 1 Exchange Rate and Shanghai Composite Index ADF Test Results

\begin{tabular}{ccccc}
\hline & T value & P value & unit root & summary \\
\hline Exchange rate & -1.584892 & 0.4888 & Have & unstable \\
$\begin{array}{c}\text { Shanghai Composite } \\
\text { Index }\end{array}$ & -0.664358 & 0.8521 & Have & unstable \\
\hline
\end{tabular}

It can be seen from the results that the p-values obtained by the two models of the Shanghai Composite Index and the RMB Exchange Rate against the US dollar exchange rate are both greater than the significant level of 5\%. It can be seen that the Shanghai Stock Exchange Index and the RMB exchange rate against the US dollar have unit roots, and the sequence is unstable.

The following article will test the first-order difference and the results are as follows:

Table 2 Exchange rate and Shanghai Composite Index first-order difference ADF test results

\begin{tabular}{ccccc}
\hline & T value & P value & unit root & summary \\
\hline Exchange rate & -15.97675 & 0.0000 & No & Stable \\
$\begin{array}{c}\text { Shanghai Composite } \\
\text { Index }\end{array}$ & -15.78774 & 0.0000 & No & Stable \\
\hline
\end{tabular}

It is obvious that the p value is not significant, so the null hypothesis is rejected, so there is no unit root and the time series is stable. From this we can conclude that the Shanghai Stock Exchange Index and the RMB against the US dollar exchange rate belong to the first-order single sequence.

\subsection{Cointegration test}

From the above analysis, it can be seen that the Shanghai Stock Exchange Index and the RMB exchange rate against the US dollar belong to the first-order single-order sequence. In order to prevent the phenomenon of pseudo-regression, the cointegration test is carried out in the following 
paper. Here we use the E-G two-part method to test its cointegration, the results are as follows:

Table 3 Cointegration test results

\begin{tabular}{ccccc}
\hline & Tvalue & Pvalue & $\begin{array}{c}\text { Stable or } \\
\text { unstable }\end{array}$ & sumarry \\
\hline $\begin{array}{c}\text { Cointegration } \\
\text { result }\end{array}$ & -2.475758 & 0.0132 & stable & Cointegration \\
\hline
\end{tabular}

Obviously, the P value is less than 5\%, and the original hypothesis is rejected. There is no unit root and it is stable. Therefore, there is a cointegration relationship between the Shanghai Stock Exchange Index and the RMB against the US dollar. Next, a regression analysis is performed, and the regression results are as follows:

Table 4 Regression Results

\begin{tabular}{cccc}
\hline & $\mathrm{C}$ & $\mathrm{X}$ & $\begin{array}{c}\text { coefficient of } \\
\text { determination }\end{array}$ \\
\hline $\begin{array}{c}\text { Regression } \\
\text { result }\end{array}$ & 0.926388 & -129.5986 & 0.876524 \\
\hline
\end{tabular}

$Y=-129.5986 X+0.926388 X$ means the exchange rate $Y$ represents the Shanghai Stock Index, and the coefficient of determination is relatively large, indicating that the explanatory variable has a stronger explanatory power for the independent variable. From the regression equation, it can be seen that the RMB exchange rate and the Shanghai Composite Index are negatively correlated, and the appreciation of the RMB, that is, the value of $\mathrm{X}$ becomes smaller, and the Shanghai Composite Index rises. This shows that the appreciation of the RMB against the dollar will cause the stock price to rise.

\subsection{Granger causality test}

From the above analysis, we can see that there is a cointegration relationship and a negative correlation between the Shanghai Composite Index and the RMB against the US dollar. Next, the Granger causality test will be carried out to further test the causal relationship between the two. The test results are as follows:

Table 5 Granger test results

\begin{tabular}{ccccc}
\hline Granger causality test & lag order & Fvalue & Pvalue & Summary \\
\hline X does not cause Y & 1 & 0.18452 & 0.6679 & Accept \\
Y does not cause X & & 4.30180 & 0.0391 & Refusal \\
X does not cause Y & 2 & 1.03554 & 0.3566 & Accept \\
Y does not cause X & & 3.29323 & 0.0388 & Refusal \\
X does not cause Y & 3 & 0.95421 & 0.4151 & Accept \\
Y does not cause X & & 2.24587 & 0.0837 & Accept \\
\hline
\end{tabular}

$\mathrm{X}$ stands for Shanghai Stock Index $\mathrm{Y}$ stands for RMB to US dollar exchange rate

\section{Conclusions}

Under the open economy, China's exchange rate and stock price have a single negative correlation. The RMB exchange rate declines, that is, the RMB appreciates, and the stock price will rise. 
Conversely, the stock price declines.

There are many factors that influence the correlation between exchange rate and stock price, such as the openness of the market, the level of improvement of the system, and the government's policies. In a country with less financial controls and a mature and open market, the exchange rate and stock price correlation will be high. Fluctuations in the exchange rate will directly affect the stock price, and the conduction speed is also very fast. But in countries where financial markets are closed and backward, exchange rate stocks are not much relevant or even irrelevant. The establishment of China's financial market is still relatively short, and the system is still not perfect. It has a big gap with developed countries in Europe and America. However, with the progress of China's share reform and exchange reform, the order of China's financial market will be more and more perfect. The correlation between China's stock market and exchange rate will also be stronger.

\section{References}

[1] Issam S. A. Abdalla,Victor Murinde. Exchange rate and stock price interactions in emerging financial markets: evidence on India, Korea, Pakistan and the Philippines [J]. Applied Financial Economics .1997, 7:25-35.

[2] Muhammad, N,Rasheed, A.Stock Prices and Exchange Rates:Are they Related Evidence from South Asian Countries[J]. 18th Annual General Meeting and Conference of the Pakistan Society of Development Economists .2003.

[3] Aggarwal,R. Exchange Rates and Stock Prices:A Study of U.S.Capital Market under Floating Exchange Rates[J].Akron Businessand Economic Review .1981,12:7-12.

[4] Richard A. Ajayi, Mbodja Mougou. on the dynamic relation between stock prices and exchange rates [J]. Journal of Financial Research. 1996, vol.19:193-207.

[5] Mohsen Bahmani-Oskooee, Ahmad Sohrabian. Stock prices and the effective exchange rate of the dollar [J]. Applied Economics. 1992, vol.19:193-207.

[6] Ali, H. S. ,Idris, M. ,Kofarmata, Y. I.Stock Prices and Exchange Rates Dynamics in South Africa:An application of Asymmetric Co-Integration Approach[J].Journal of Economics Library,2015,2(3):165-172.

[7] Sui, L. ,Sun, L.Spillover Effects Between Exchange Rates and Stock Prices: Evidence From BRICS Around the Recent Global Financial Crisis[J].Research in International Business and Finance,2016,36:459-471.

[8] Koulakiotis A, Kiohos A, Babalos V. Exploring the interaction between stock price index and exchange rates: an asymmetric threshold approach [J]. Applied Economics, 2015, 47(13): 1273-1285.

[9] Husam Rjoub. Stock prices and exchange rates dynamics: Evidence from Merging markets [J]. Caw Journal of Business Management, 2012, 6(13):4728-4733. 